ISSN: 1641-4713; e-ISSN: 2081-1160

DOI: https://doi.org/10.36551/2081-1160.2020.26.39-62

\title{
Yaô Africano: the Orixá in the Voice of Patricio Teixeira
}

\author{
Yaô africano: los orixás en la voz de Patricio Teixeira
}

\author{
Caroline Vieira
}

Rio de Janeiro State University, Brazil

ORCID iD: https://orcid.org/0000-0002-3431-6551

E-mail: carolinemvieira.prof@gmail.com

Joana Bahia

Rio de Janeiro State University, Brazil

ORCID iD: https://orcid.org/0000-0002-2172-5022

E-mail: joana.bahia@gmail.com

Recepción: 30.04.2020

Aprobación: 6.08.2020

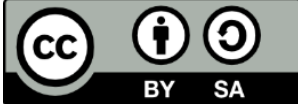

\begin{abstract}
Patricio Teixeira was an important voice in Brazilian music, particularly during the 1920s and 1930s. His career in radio broadcasting extended into the mid-1950s. Teixeira's work gave visibility to black subjects and their cultural identities. This article analyzes the sacred elements that overflow into the musical and recreational universe of Rio through some of the songs recorded by Teixeira. With varied appropriations, these recordings of chants for orixá, AfroBrazilian practices, and rituals mark the presence of the Afro-Brazilian sacred in Brazilian popular song.
\end{abstract}

Keywords: Patricio Teixeira, trajectory, black cultural identities, Afro-Brazilian religions, popular music.

Resumen: Patricio Teixeira fue una voz importante en la música nacional, especialmente en las décadas de 1920 y 1930, y su carrera en la radio se extendió hasta mediados de la década de 1950. Su experiencia ha dado visibilidad a los sujetos negros y a sus identidades culturales. Este artículo analizará los elementos sagrados que se desbordan en el universo musical y lúdico de Río de Janeiro a través de algunas canciones grabadas por Teixeira. Con apropiaciones variadas, las grabaciones que cantan orixás, prácticas y rituales afrorreligiosos demarcan la presencia del afrobrasileño sagrado en el canto popular.

Palabras clave: Patricio Teixeira, trayectoria, identidades culturales negras, religiones afro-brasileñas, canciones populares. 


\section{INTRODUCTION}

Between the 1920s and '50s, a black singer's voice echoed out from the record players and across the radio waves in Brazil. Much appreciated for his vocal and guitar skills, Patricio Teixeira became nationally famous and received social recognition for his art, despite his later neglect in the historiography of Brazilian music. Singing sambas and carnival marches, emboladas and country songs, romantic modinhas, African lundus, samba jongo, and "black dance hall music", Teixeira projected his black identity into the songs he sung and played. In his repertoire, there was even a place to sing orixá chants. ${ }^{1}$

A poor, black, orphaned boy, Patricio was born in the city of Rio de Janeiro, just four years after the abolition of slavery in 1892. He grew up in the neighborhood of Estácio and Praça Onze, a region that disappeared from the Rio de Janeiro urban landscape in the 1940s with the construction of Avenida Presidente Vargas. This neighborhood was located in the parish of Santana, one of the most populous in the city of Rio de Janeiro, with a large number of black residents (Cunha, 2001, pp. 165-166).

Subverting social expectations for the blacks of the times, Patricio Teixeira was very successful as a singer, especially in the 1920s and 1930s. His songs were played inside homes, commercial establishments, and the festive spaces of various social classes. Radio spread his voice even further. His so-called stage recitals also gave him social prestige among Rio's intellectualized elites.

One can find Patricio Teixeira's photograph being exhibited in the newspaper Correio da Manhã in 1926 in the section entitled "That which is ours". This column talked about popular music and discussed Brazilian senses of heritage and national belongings in the realm of music.

Although sambas and batucadas were snubbed in Rio due to elitist and racist biases, there were places for black music in the recording studios and on the airwaves of the 1920 under the rubric of "folklore" and following the growth of the nationalist ideology of miscegenation. It was in the context of this controversial debate and in this musical scene that Patrício Teixeira stood out as a singer, presenting "popular songs" on several radio stations and recording albums from the mid-1920s on.

\footnotetext{
${ }^{1}$ This study was financed in part by the Coordenação de Aperfeiçoamento de Pessoal de Nível Superior - Brasil (CAPES) - FinanceCode 001 (Dantas, 2019).
} 
IMAGe 1. PATRICIO TeIXEIRA

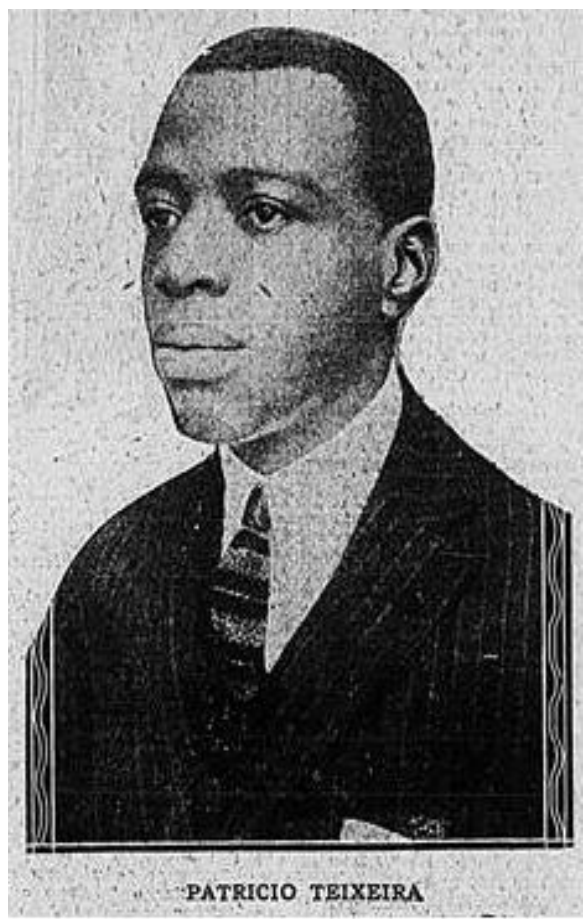

Source: Correio da Manhã, suplement, 09/19/1926, p. 9.

Songs very similar to Afro-Brazilian sacred music or inspired by the city's religious spaces were recorded or played on the radio, using language, pronunciations and vocabularies very similar to those found among Rio's AfroBrazilian religious groups. In some songs, greetings are heard evoking orixá and, at the end of songs, the closing sounds of spiritual works are worked into the musical background with rhythms and drums.

The Afro-religious universe is and has been an important source of inspiration for the popular song composers in Brazil. This intertwining has been evidenced since the beginning of the audio recording process in Rio de Janeiro, with Casa Edison in the early years of the 20th century. Recording became a means for black musicians to gain space, social recognition and professional prestige, but it also opened up channels for the communication of world views and identity bonds in dialogue with the phonographic market throughout the first half of the 20th century. These included the symbologies of the AfroBrazilian sacred (Vieira, 2010). 
This intertwining between artistic performance and religiosities manifested Afro-Brazilian views and beliefs outside the terreiros, marking the presence of the Afro-Brazilian sacred in the larger Brazilian cultural universe. This process can be seen in the trajectory of another prominent character in the Rio de Janeiro artistic scene of the times. Joãozinho da Goméia, dancer and pai-desanto, collaborated in the expansion of the Afro-Brazilian religion by connecting art, religion, sexuality, and African cultures. He appeared on radio programs and gave interviews to newspapers and magazines, seeking to increase his social prestige, promote candomblé and help disseminate religious symbols. He inserted the sacred dances and aesthetics of the orixá in performances in shows and in the parades of the city's samba schools (Bahia \& Vieira, 2017).

We can identify correlations between popular musicalities and AfroBrazilian religions throughout the first half of the 20th century. These findings demonstrate that Afro-Brazilian religions are dynamic and that their practices and representations are constantly changing, influencing the artistic scene and, in particular, musical activities. The exchanges between one realm and the other were open, socializing expressions of ritual, which could even work to expand the range of religions' social visibility.

Our objective in the present article is not to identify elements of a given religion in recorded popular songs, but to follow Capone (2004, pp. 21-31) in suggesting that the entire Afro-Brazilian religious field is a continuum. It is not possible to speak of Candomblé, for example, without mentioning the other belief systems that belong to the same religious universe and that help to define its borders in an identity construction process.

We noticed the use of various expressions whose origins can be found in the Afro-religious universe in popular songs recordings. Symbologies, practices, rituals and spiritual entities were a source of inspiration for composers who moved between public and sacred Afro-Brazilian spaces. These religions were not kept apart from society in general. On the contrary, they existed in a dialogue and interacted with society at large, possibly facilitating the overflow of their ritual practices, spiritual entities, and religious beliefs. The meanings of this expansion are multiple, generating particular (re)appropriations. These range from folkloric to playful and/or desecrating representations. In any case elements of the religions were present in the songs from this period, giving the religions a public visibility that extended beyond the immediate circles of the faithful. This expansion could also produce religious meanings that would touch individual lives in the city, depending on individuals' level of proximity to Afro-Brazilian religion. It certain- 
ly widened the range of recognition for sacred symbols in other spaces of the city not generally associated with black populations or cultures.

João do Rio, a chronicler and urban observer active in Rio at the beginning of the 20th century, described in detail the places, rites, and people that attended the city's various religious rituals, pointing out relations based on tensions, conflicts, and social interactions. Employing an ironic tone and sometimes demonstrating his own prejudices, João do Rio made important observations about the religious universe of Rio de Janeiro. According to his writings, "the city is teeming with religions. Just stop at any corner and ask. The diversity of the cults will amaze you." (Barreto, 1951, p. 9).

These descriptions illustrate a city where belief in spells is widespread and interwoven in people's lives. João do Rio did not treat the "world of spells" (a title of one of the chapters of his book The Religions of Rio; Barreto, 1951), as something set from the city's larger social life. Instead, he took an integrative approach, emphasizing the connections religions made to and between the city and its inhabitants.

From these reports, it is not difficult to perceive an intense exchange of knowledge and religious experiences among the inhabitants of Rio. Pais and Mães de Santo, often known as "Uncles" and "Aunts", moved through the entire city at the turn of the $20^{\text {th }}$ Century, working in small shops, selling sweets and other food on the street, providing sewing and cleaning services, and participating in carnival parties and groups. These men and women took the Afro-Brazilian cults beyond their spaces of origin in Downtown Rio. This attracted other social groups and enabled the formation of networks that were interwoven through the religious field, influencing cultural production and, particularly, music.

Our understanding black musician Patricio Teixeira's performances must be cast against the backdrop of this artistic scene. Following his musical choices, we can even reflect on the place of black identities in "popular music", as well as on his interrelationships with Afro-Brazilian religions. However, the diversity of what Patricio recorded and sang on the radio and on the stage does not allow him to fit into just one musical genre or style. His repertoire was wide and varied. It included modinhas, emboladas, popular songs, country songs, lundus, jongo, batucadas, maxixes, sambas and marches. Patricio recorded sambas in the 1920s at the beginning of his phonographic career (when the mainstay of his repertoire was the Northeastern genres), but also sang country songs in the mid-1930s, when carnival sambas came to dominate his discography. 
Patrício's greatest fame was as a singer and guitarist. He also, however, was a composer, writing some of his own songs. In an interview given to the Museum of Image and Sound of Rio de Janeiro in 1966, he claimed that he did not write many songs because there were already so many talented composers in the city (Teixeira, 1966). We do not know to what extent composing was part of Patricio's artistic interests, given that he was successful as a singer and was renowned as a guitar player. Having built a successful career with records and on the radio, he was much sought out by composers in order to record their songs and sing them on radio Mayrink Veiga, the main broadcaster where Patricio worked for three decades.

The fact is that Patricio did not invest in composition as much as he did in singing and guitar playing, and this fact indicates the paths he followed in Rio's artistic scene. As he said, competition in the composition scene was very great at the time. Singers - and particularly radio singers - were scarcer on the ground, especially so in the 1920s and 1930s. Patricio was therefore very comfortable in his position as radio singer and had little objective reason to invest in songwriting.

In the same interview mentioned above, Patricio insinuated that he had not asked for co-authorship in some of the songs he did indeed help compose, especially by contributing ideas. His statements suggest that he did not need to ask for partnerships, and argue for the fact that it was the singer who had greater prestige at the time. Patricio spoke of this perception in relation to singers and composers, casting the first function as being more socially valued than the second. His notes also contain a tone of criticism. According to Patricio, "his name [the name of the singer] prevailed; the rest nobody wanted to know (...) the guy sings there, people only know the music by the [name of the] singer. It's so-andso, the singer." The "author had no place, only the singer" (Teixeira, 1966). It is significant that these words were spoken by a musician who mainly worked as a singer, being one of the most well-known performers of the period.

It is thus worth reflecting on the singer's role in the process of choosing his repertoire. It is clear that there were mediations in this process to which the singers were subordinate: artistic directions, for example. On the other hand, successful singers had some weight in negotiating what they were going to record. They frequented bars, circulated in the streets, and had relationships with experienced composers and those who dreamed of having their songs recorded by a renowned singer. Nuances permeated what one recorded. One could choose, for example, to favor one's closest friends, gaining authorship or coauthorship, which could imply financial gains through copyrights. 
In any case, what the singer recorded was not a random choice, as it involved reflections on the song itself. A successful singer needed to be tuned in to the city's moods in order to perceive what would be a potential success. The most outstanding singers were sought after by many song writers who wanted to show off their compositions. This sorting process may thus reflect a bit on the singers, their identities, their interests, their affinities and their view of the world - not only as artists, but as individuals. After all, it is not possible to draw strict limits between the two roles.

References to singers as "creators" are found in the periodicals I analyzed, in the specialized radio and music columns. One often sees things like the attribution of a song in the following manner "Creation by Patricio Teixeira", even though Patricio was not the composer. The use of this term to qualify the work of the singer indicates that this is an operation of qualification, distinction, and selection. The singer had his share of responsibility for the success or failure of a given song with the audience. Being defined as a creator almost suggests a co-authorship, taking into account the fact that the act of singing can be found in interpreting, experiencing, and expressing the personality of the song in a particular way. In this social construction of musical production in early $20^{\text {th }}$ century Rio de Janeiro, the performer would almost always be more remembered (unfairly) for a song than its composer.

From what the sources indicate, this is how a singer was socially understood. Following this perspective, we will now analyze some songs from Patricio Teixeira's, understanding that the process of choosing what songs to sing is dynamic and can give clues about the singer's subjectivities and identities, as well as highlighting his social relationships.

\section{SAMBA DE FATO: SONGS AND AFRO RELIGIOSITIES}

The song by Pixinguinha and Cícero de Almeida recorded in 1932 by Patricio Teixeira, with the presence of a large number of rhythm instruments, tells us what a Samba de Fato or a "real samba", is:

Samba de partido alto

Only cabrochas who can really samba will go to it

Only mulattos sons of Bahian women go

And rich people from Copacabana

Docs with their golden doctor rings

Scented white people with blonde hair, olé

Also blacks who are good people

We give crowns to graceful creoles 
Because blacks have rank in the samba

There are melodies that treat us badly, olé

The tambourine moans and the guitar cries

Until dust rises from the ground

Partido alto is a fast-paced samba

And it continues until the break of day

And when the samba is really mad

Then our eyes roll back

And if there is any disharmony

Everyone winds up in the precinct house, olé

When the samba ends at dawn

We have shaky legs

And our bodies long for bed

All night long, just cutting the rug, olé

Your mouth has a bad taste

Like an old wooden spoon's handle

Because if there's no cachaça at the samba

People get angry and start a fuss, olé ${ }^{2}$

Pointing out elements of sambas that have a sense of community celebration, the verses describe the roda, its participants, instruments, Afro-religious influences, and the social control exercised over it by the repressive forces of the police. It sequentially establishes the stages of the samba circle, ending with the next day's hangover (for, after all, cachaça - Brazilian sugar cane brandy was an essential part of the event). This was a description of a partido alto or "high party", that is, a "real samba" in its "original" form, very different from the environment of the phonographic and radio studios with their formalities, equipment and technical staff that did not share the same cultural meanings.

The partido alto was, in the concept of the samba circles of the past, a designation for instrumental samba, which could occasionally contain vocalizations. When singing came into it, it consisted of a solo part called the "chula" (samba-chulado or chula raiada) and a chorus. This expression, already in use in modern times, also indicated sambas sung in the form of a challenge by two or more soloists. These were also composed of a chorus and solo parts. Only "highly respected people" participated in it, so the word "partido" - or party referred to a group of people who were of "high quality" and composed the samba circle. Hence the adjective "high" refers here to the idea of "excellence" (Lopes \& Simas, 2015, p. 211).

\footnotetext{
${ }^{2}$ The original in Portuguese was transcribed with the pronunciation errors of the singer. It is important to point out that the composers of the songs we are dealing with here were part of Patricio Teixeira's social circle from his younger days on. This is the case with Pixinguinha (1897-1973), compositor, orchestrator, flautist, and saxophonist.
} 
From a socio-historical point of view, Samba de Fato reveals the circulation and cultural sharing of individuals of different origins. Differentiations were present at the partido, classifying samba participants into social and racial categories in line with their modes of social identification. Thus, Copacabana is revealed as the place of the "rich people", from whence come the "doc[tor]s with their golden doctor rings" and where the "scented white people with blond hair" live. These are situated in direct contrast to the "mulatto sons of Bahian women", the "blacks who are good people" and the "creoles" (a term that is reserved in Rio for people of visible African descent) who win "crowns" for being "graceful".

In the samba circle, social and racial hierarchies are subverted and the command hierarchy inverted. Thus, "blacks have rank in samba", unlike the greater urban reality, demarcated by a racially established social structure. The "rich people", white men and women, participated in the circle, but with blacks held primacy in its leadership. In samba, it's the blacks who dealt the cards.

These verses were representations of the social places occupied by whites and blacks in early $20^{\text {th }}$ Century Rio de Janeiro. References were made to the old times of the samba de roda, indicating black musicians' struggle to symbolically and politically demarcate their original role in constituting this cultural manifestation. After all, the recording was made in 1932 in the midst of samba's transformation into a form of merchandise appropriated by the most diverse Brazilian social segments. ${ }^{3}$

We must point out that this debate would frequently oscillate between emphasizing the harmony mixing brought to Brazilian society (including the field of race relations: Vianna, 2004) and highlighting samba's undisciplined nature (Wisnik, 1983). For Hertzman (2013, pp. 7-9) the transformation of black cultural production into national symbols involved deep tensions and inequalities that produced the racialized hierarchies and stereotypes that limited black composers' social mobility.

The valorization of popular cultures was premised upon "hygienization", a purging of the elements considered to be "barbaric", "savage", and "uncivilized" within folk traditions (Napolitano, 2010, pp. 424-430). State actions were

\footnotetext{
${ }^{3}$ Throughout the government of Getúlio Vargas (1930-1945), samba was considered to be a mark of Brazilian national identity. The relationships between popular composers and musicians and the intellectuals of the time have been analyzed elsewhere by many different authors (Wisnik, 1983; Vianna, 2004; Abreu \& Dantas, 2007; Napolitano, 2010). Vargas took power in 1930 as a provisional president through the so-called Revolution of 1930 and remained in power until 1945. From 1937 to 1945, he led Brazil under the dictatorship of the Estado Novo ("New State", Pandolfi, 2007, pp. 13-37).
} 
thus characterized by a certain tension within intellectual and governing groups when it came to the legitimization of samba (Paranhos, 2015, p. 50). In this way, fractures in repressive controls permitted songs to circulate that referenced African heritages. Some of these songs were recorded or sung on the radio by Patricio Teixeira.

Returning to our analysis of the song mentioned above, recorded by Teixeira in 1932, a fundamental aspect on display here is the interface between "samba de partido alto", considered in the song to be "real samba" and AfroBrazilian religions. The verses "when the samba is really mad /Then our eyes roll back [into our heads]" indicates the internalization of religious ritual practices in the samba environment. At the moment when samba is "mad", agitated or nervous, the "saints come down": in other words, the participants "eyes roll back" as they are possessed. ${ }^{4}$

The links between samba's origins and Afro-Brazilian religions are thus revived by the samba dancers themselves. For Heitor dos Prazeres" "the origin of samba is candomblé, it is macumba", but "I did not to mess with religious songs because I had respect for not being punished [sic] (...) then we did those things [samba, cateretê] for people to play with" (dos Prazeres, 1966). João da Baiana $^{6}$ also points to this separation between the moment of the sacred and that of fun: "Candomblé was a separate party" and "samba came after the ritual" (samba de roda). However, the verses in the song above indicate that the boundaries between the sacred and the profane were much more porous than some might think (da Baiana, 1966).

There are songs in Patricio's repertoire that make reference to the candomblé orixá. This is the case of Dona Clara, written by Donga ${ }^{7}$ and João da Baiana and recorded in 1927:

I was in Dona Clara / At a macumba

With Exu speaking / Casting a spell

On you / So that you would leave me

But you woman / Have a strong saint

And don't want to leave me / She's a daughter of Ogum

A niece of Xangô / A granddaughter of Oxalá

\footnotetext{
${ }^{4}$ The medium is possessed by a spiritual entity. "Samba" itself has many different meanings, one of which is the woman who is the ekédi, the assistant to the children-of-the-saints while they are in a trance or performing sacred dances. She is also the assistant of the mãe pequena in those temples that have a Bantu influence (Cacciatore, 1977, p. 226).

${ }^{5}$ Heitor dos Prazeres (1898-1966) was a Carioca musician and composer.

${ }^{6}$ João da Baiana (1887-1974) was a Carioca composer and tamborine player.

${ }^{7}$ Donga (1890-1974) was a Carioca composer and guitar player.
} 
If the spell doesn't take / My saints are going to tie you up

A preta velha [an old black woman] / With a crooked pipe

That she had in her mouth / Called me over to a corner

And told me, quietly / This woman is crazy

Get three sticks / Toss them in the air

At the crossroads / The lord is going away

And told me on the sly / This woman is tied up

You disdain me / You abandon me

I don't know why / I am going to ask for vengeance

From my guardian angel / So that you suffer

I implore God / At midday on the dot

With my hands stretched to the sky / I will see you in the street

Wearing a sack / And gathering waste paper. ${ }^{8}$

This samba references elements of Afro-Brazilian religions, such as their spiritual entities and ritual practices. The verses tell the story of a love relationship in which the man wants to separate from the woman, but she insists on maintaining the relationship. The man thus seeks help at a "macumba" to solve his problem. To cast a spell so that the woman will leave him, he resorts to Exu, the orixá who is the mediator and communicator with our world and the beyond. However, the woman has a "strong saint" and was a "daughter of Ogum", "niece of Xangô" and "grand daughter of Oxalá". This prevented the problem from being solved. A "preta velha" is also consulted. ${ }^{9}$ Being the daughter of Ogum, the saint of warfare, this woman would have a firm temperament and character and would therefore be difficult to fight, according to the Afro-religious view. In Ogum's line, one finds Xangô, king of lightning and thunder, and Oxalá, orixá who presided over the creation of humanity and is responsible for governing it.

The inspiration for the following lundu, Yaou Africano, (1938) also came from Afro-Brazilian religions:

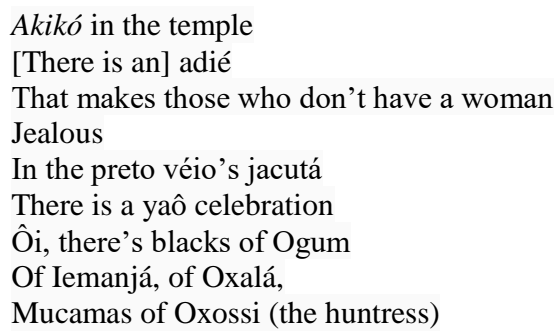

\footnotetext{
${ }^{8}$ Dona Clara is the name of a street in the neighborhood of Madureira in Rio de Janeiro.

9 "To be tied up" means to be locked into place, metaphorically, in one's life and business after being hit with bad vibrations (Cacciatore, 1977, p. 48). The "old black women" (sorceresses and mães-de-santo) are the female priestesses of the Afro-Brazilian temples. Their word is law, and they are due respect and obedience. They are able to communicate with the transcendental in order to conduct extraordinary magical feats, both positive and negative (Cacciatore, 1977, p. 166).
} 
Well, long live Nanã

Nanã Borocô / Yô yôo

Yô yôoo

In the preto velho's temple, iaiá

Let's hail saravá (to whom, my father?)

Xangố! $!^{10}$

Here, the composer employs several African words he appropriated from Yoruba used in Candomblé. This begins with the title, Yaô Africano, which alludes directly to the continent of origin of these religions, which are recreated and re-signified in Brazil (Capone, 2004). The song narrates a feast of Yaô (or iaô), which is the initiation ritual in candomblé. This word refers to the name given to the person to be initiated into the religion (Cacciatore, 1977, p. 140).

The celebration took place "in the preto véio's jacutá", a word that has different meanings such as a temple, altar, or house where the saint lives. ${ }^{11}$ The old blacks (preto velhos) are spirits of former African slaves in Brazil who are characterized by purity, wisdom, and kindness, which is why they are sought out as advisers. They smoke pipes and use a peculiar language, close to the spoken vernacular, which was conventionally called "black language" in Rio. This can be observed in some words in the song's lyrics, such as "muié", "preto véio", "nega" and in the form of chanting instead of singing the words.

The animals used in rituals in that temple, akikó (rooster in Yoruba) and adié (hen), were the envy of those who had no wife. In the song, the orixá of the "blacks" belonging to Ogum, Iemanjá and Oxalá began the ceremony, along with the "mucama of Oxossi", the orixá of the hunt. Finally, the composer greets Nanã Borocô, an elderly female orixá. $^{12}$

At the end of the lundu, an orixá is greeted in a peculiar way: "Let's hail saravá (to whom my father?) / Xangô!" This use of Xangô as a "father" means the singer is a child of that orixá. Pixinguinha was a son of Ogum, so was Gastão Vianna, the other composer, a son of Xangô? Or perhaps it was the singer?

In Yâ̂ Africano, we also see the marked presence of percussion instruments. The rhythms they play remind us of macumba "point" (sacred song), as does the song's melody - being sung in this case by Patricio Teixeira - which is

\footnotetext{
${ }^{10}$ This was re-recorded in 1940 with Pixinguinha singing under the title Yaô (Victor, $\left.\mathrm{n}^{\circ} 800692\right)$. The words transcribed here are from Patricio's version, which is slightly different from Pixinguinha's.

${ }^{11}$ Jacutá is a term used in candomblé and it can also be a title given to Xangô. It refers to the 5th day of the Yoruba week in which Xangô is worshipped. Available at:

http://portaldasgirias.blogspot.com/2011/08/significado-de-palavras-e-termos-usados.html

${ }^{12}$ The eldest goddess of the waters, she is connected to death due to her advanced age. She is also considered to be the orixá of the rains (Cacciatore, 1977, p. 179).
} 
immediately repeated by the choir. In addition to these aspects, there are the characteristic syncopated rhythms and lyrics dealing with themes of AfroBrazilian religions. These characteristics suggest an identity that brings the song closer to the religious songs of the day. ${ }^{13}$

Em festa de Nanã, an African lundu from 1941 by the same duo of authors who wrote Yaô Africano, the celebration would be directed to that orixá. The chorus, in Patricio's voice, said:

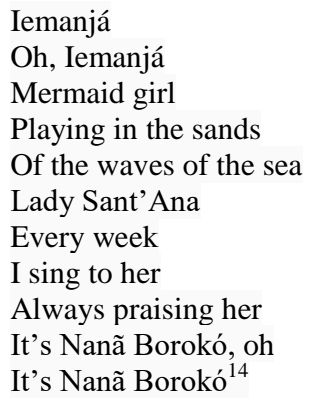

Note the use of very specific terms in this song that require a degree of approximation, knowledge, and experience with Afro-Brazilian religious services. The composers mobilized religious values as their inspiration for the song. While affirming their beliefs for themselves, they also took them to wider social spaces through popular music on a record, played and sung by instrumentalists and performers such as Patricio Teixeira. In 1938, Patricio would also record Mulata Baiana, a samba-jongo written by the same duo of composers.

Composers like Pixinguinha and João da Baiana who openly declared their affiliation with candomblé by mobilizing religious references in their songs were, perhaps unpretentiously, affirming their identities while spreading religious meanings throughout Brazilian society and the other cultural spaces frequented by their songs' singers. Patricio's choice as an interpreter of these songs does not seem to be arbitrary. I also suppose that the singer had a choice in following this theme. After all, since his youth, Patricio had been a part of the social network of these songs' composers.

\footnotetext{
${ }^{13}$ Syncopation refers to a melodic inflection that alters rhythmic regularity. A rhythm of a measure is regular when it "likes itself to the regular time units provided for in the measure". The opposite occurs when it is syncopated (Bessa, 2006, p. 58). For a study of the musical aspects of samba and other genres of which it is tributary, as well as rhythmic comparisons with African and European standards, cf. Sandroni, 2001; Lopes, 1992.

${ }^{14}$ One can listen to these and other songs at https://pixinguinha.com.br, a webpage organized by the Instituto Moreira Salles commemorating the composer's $120^{\text {th }}$ birthday.
} 
Although the songs are in the realm of art and are sometimes conceived of by the press and by some intellectuals as belonging to the realm of "folk music", a black artist singing songs that refer to Afro-Brazilian cults took a risk of being stereotyped. He could have his image associated with slavery and, ultimately, with Africa, considered by many people to be a savage and barbaric continent.

Maggie's analysis presented in O Medo do Feitiço (1992) describes the religious scenario of the First Republic in Brazil as marked by widespread belief in the ability of people to promote harm or benefit to others through sorceries and spells. This belief was still widespread a generation later (and, some would argue, today) According to Maggie, the 1890 Republican Penal Code ${ }^{15}$ and the legal and police apparatuses that regulated and repressed magical practices did not target all forms of Afro-Brazilian worship, only those sorcerers considered to be promoters of "evil magic". A hierarchy was established that classified religious groups as purveyors of "good" or "bad" spiritism. This, in turn, ended up establishing relativizations in the repressive practices in relation to AfroBrazilian religions. What deserved punishment would be increasingly understood to be those religious practices more focused on African heritage, considered to be "primitive", "barbaric" and "savage". 16

The early years of the Getúlio Vargas government in Brazil (19301945) demarcate continuities with regards to the practice of persecution of Afro religious groups, despite a turn towards increasingly valuing popular cultures, including samba. However, repressive and control measures continued to prevail in the Afro-Brazilian religious world (Conduru, 2010, pp. 181-182). ${ }^{17}$

\footnotetext{
${ }^{15}$ There was an intensification of anti-Afro-religious repression with the beginning of the Old Republic, which criminalized "witchcraft" and "healers". Prison sentences and fines were decreed for "spiritism, magic and sorceries", provided for in Article 156 of the Penal Code of 1890. Decree of October $11^{\text {th }}, 1890$. Rio de Janeiro: Imprensa Nacional. It is important to highlight that these persecutions extended up to the enactment of the 1939 prohibition decree, according to Conduru (2010, pp. 181-182).

${ }^{16}$ Conceptions of so-called "low spiritism" can also be observed in Giumbelli (2003, pp. 247-281). In the case of Bahia, Dantas (1988, pp. 145-216) demonstrated that there were differences in the treatment of those temples designated as being "guided by tradition", with these gaining a certain degree of legitimation. While some temples were violently repressed, others were protected by intellectuals and segments of the elite. The Nagô temples, considered to be more traditional, would suffer less from police repression than the "caboclo terreiros", which were considered to be mixed and syncretic. This favored the construction of a candomble model that would become hegemonic in Bahia: the jeje-nagô. Capone (2004) also undertakes an important discussion about candomblé and its links with Africa.

${ }^{17}$ The 1939 decree that prohibited persecution of Afro-Brazilian religions coincided with the deaths of the principal religious leaders of the city: Rodolfo Bamboxê, João Alabá, Cipriano Abedé and Mãe Aninha. Cf: Conduru (2010, pp. 181-182).
} 
Amid debates about classifications, traditions, repressions, controls, and negotiations, there were spaces in the music market for songs that disseminated religious values and symbols. Spells, ebós, macumba "points" and spiritual entities were being spread through urban life far beyond their sacred redoubts as products were bought and listened to. They would certainly produce different interpretations by the most varied of interlocutors, such as listeners, phonographic and radio companies and their agents. In this way, these songs assumed meanings that were simultaneously playful, commercial, and religious, collaborating to bring the Afro-Brazilian sacred closer to the popular Brazilian musical universe (Vieira, 2010).

The links between popular music and religions of African origin are still noticeable today, indicating the power of influence and social penetration of this worldview, despite all the prejudices and repressions it faces. In a direct or diffuse manner, through lyrics, through forms of singing, or through the use of other musical devices, the correlations between phonography and Afroreligiosity were already visible in the first phonographic recordings made in Brazil in the early years of the 20th century, when these religious practices were still criminalized (Vieira, 2010). Through particular appropriations, their mark would indelibly be disseminated in Brazilian phonographic productions over time, crossing genres, styles and regions. ${ }^{18}$

Even though they could take on folkloric connotations and an exoticism that distorted their religious meanings, these songs could also denote forms of struggle by black cultures and their agents in the musical field. They perpetuated the presence of religious symbols in the artistic field in spite of depreciations, persecutions, and regulations. The expansion of the social circulation of Afroreligious elements (themes, sounds, instruments, ways of singing, performances) even pointed to possible forms of identity resistance in cultural contexts.

If, on the one hand, addressing these themes made the symbolic universe of the Afro-Brazilian religions come to the fore in popular musical tastes, on the other hand, it linked blacks to images of sorcery and witchcraft. Remains of the racist theories of the late 19th and early 20th centuries hovered (and still hover) in Brazilian common sense, as indicated in prejudiced press reports that targeted Patricio Teixeira. Just as Afro-Brazilian religions and their followers faced discrimination and even persecution, black artists could have their image

\footnotetext{
${ }^{18}$ Studies regarding this theme have been undertaken by Prandi (2005), Amaral and Silva (2006), Vieira (2010), Araujo (2015), Soares (2016), Vieira and Nogueira (2018).
} 
socially depreciated by performing chanting songs that referenced Africanbased religions. ${ }^{19}$ It is not possible to track the public's impressions of these, in general, but according to some press records we can construct an idea of how these connections were made.

By singing these songs, Teixeira affirmed his black identities on the record and on the radio, but also took certain risks. In addition to the Afroreligious themes present in some of his songs, Patricio recorded a lundu when this genre was practically forgotten by the music industry and was even ridiculed, as we can see below:

\section{IMAge 2 - PoEm ABout Patricio TeIXeIRA}

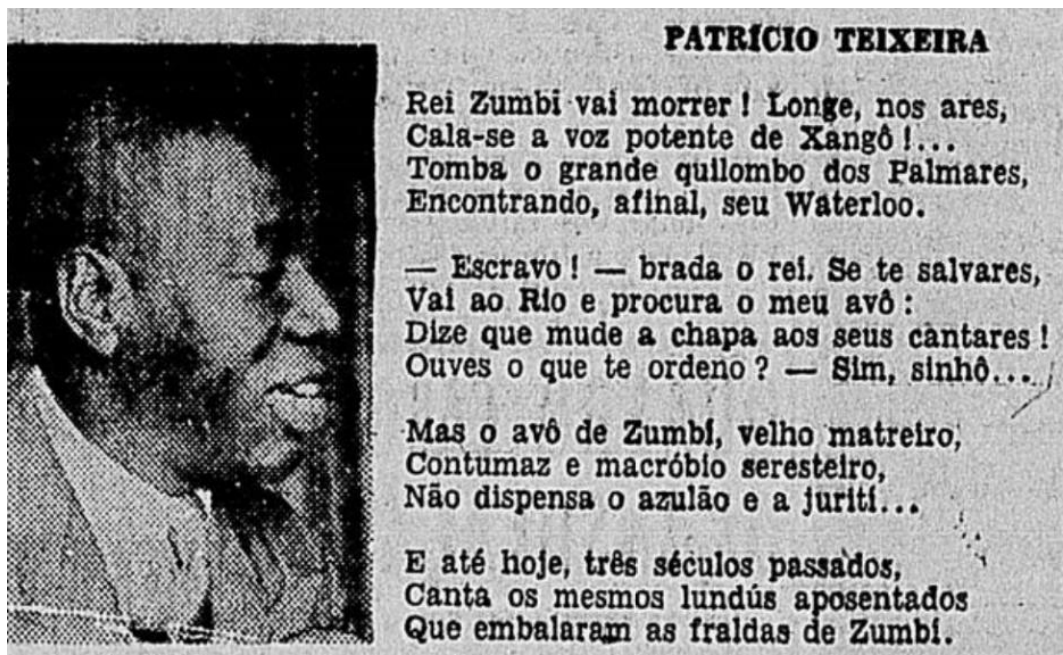

Source: A Noite, $1946 .^{20}$

This text, published alongside the photograph of Patricio Teixeira, refers to slavery times, referencing Zumbi of Palmares, the leader of Brazil's most famous quilombo (escaped slave community), who was (and is) synonymous

\footnotetext{
${ }^{19}$ When Yâ was recorded in 1938, repression of Afro-Brazilian religions was still occurring. As an example of this, Mário de Andrade needed police authorization in order to undertake the Folklore Research Mission's collection of music from the temples of Brazil's North and Northeast, (Amaral \& Silva, 2006, p. 195).

${ }^{20}$ King Zumbi is going to die! Xango's powerful voice will be silenced in the air....! The great quilombo of Palmares has fallen, having met its Waterloo! / "Slave!" shouted the King. "If you are to be saved, go to Rio and seek out my grandfather and tell him to change his tune! Do you hear my orders?" "Yessir," said the slave. / But Zumbi's grandfather, the crafty old stubborn and macrobic bard, will not give up the azulão and jurití... / And 'til today, three centuries later, he sings the same tired lundús that once wrapped Zumbi’s diapers.
} 
with struggle. In the face of his imminent death, Zumbi, "Xangô's potent voice", orders a slave to seek out his grandfather in Rio de Janeiro. Patricio thus becomes Zumbi's grandfather in this poem! The king of Palmares has a request to make of his imaginary grandfather: that he changed "his tune". Insistent, "the crafty old stubborn and bard" does not follow the advice of his grandson and persists in singing "the same tired lundús that once wrapped Zumbi's diapers", as resistant as the leader of Palmares.

In addition to the evident effort to emphasize Patricio's "old age", the image of blacks in the 1940s is here also perceived as being directly associated with slavery. Links with spiritual entities of African-based religions in Brazil were also explored in the poem, with Xangô ${ }^{21}$ being directly mentioned. Even public figures like Patricio, a radio singer and recording artist since the 1920s, were not spared this sort of criticism. They were, in fact, perhaps even more exposed to prejudice.

The poem identifies Patricio as an "old" musician in a pejorative way. Casting him as "old" seems to be a subtle way of saying that he was associated with what was considered to be primitive, outdated, and obsolete in Brazilian society: that is, black individuals and their cultural production. Within the subtleties of the gears of racism, "primitive" here seems to be disguised by the epithet "old". Given this, does Patrício's insistence on maintaining his career connote the persistence of old and "primitive" black songs? Metaphors can be very revealing of social meanings. These clues revealed here contribute to our understanding that the disqualification of Patricio produced by the poem aimed at both his musical production and at his person as a black subject.

The purpose of the poem was to comically classify Patricio's songs as old and outdated. If this were the poem's only objective, however, its criticism could have been based on contemporary aesthetic references. Recalling past times in the history of black struggle in Brazil, the poem supports the view that Patricio's songs in the 1930s and 1940s were in and of themselves pejorative, derogatory, and prejudiced. Thus, the choice to sing Afro-religious themes and lundus, a genre associated with black culture, was a risk that Patricio took which, consequently, publicly affirmed his black identity.

The compositions understood as "lundus" in Patricio's discography have been analyzed above: Yao Africano (1938); and Em festa de Nanã (1941). It is

${ }^{21}$ Xangô is a powerful Yoruba (nagô) orixá, god of lightning and thunder (Cacciatore, 1977, p. 249). 
thus appropriate for us to describe the genre. Even though there is no consensus regarding it, possibly having its origins in the dancing and drummings of black slaves, lundu became a musical genre - "lundu-canção" - in the late 18th century, and was transformed into an urban genre in the 19th century. That it was a popular and black genre is something all analysts agree upon. Lundu interested Brazilian elites, entering the halls of the big houses, but usually associated with humorous texts written by authors from the upper classes, who changed its name to changing the name to "lundu-canção". The modinha, a contemporary of the $l u n d u$, was identified as white, noble, and European origin. Both genres were thus racialized, but converged when they were imputed with a national and popular character. Appropriated as music produced in Brazil, they became national symbols in the 19th century (Ferlim, 2006). A similar process occurred with samba (but with much more intensity and scope) in the 1930s and 1940s, beginning with its elevation as a national art form by the Vargas government (Vianna, 2004).

Other genres recorded by Patricio refer directly to black cultures, such as the song Minha Combuca, ${ }^{22}$ classified as a "black dance" (and whose record I unfortunately could not find). This song's composer was known by the nickname of Príncipe Pretinho (Little Black Prince), baptized as José Luiz da Costa. The Pai Miguel Samba, from 1943, features a "macumbeiro" who charged for his services and who gave advice to others, such as ordering them "to make an offering to the saints to clean" themselves:

I know an old man who is a é macumbeiro

But he only does spells

For those who give him money

If you don't have a penny

He'll tell you this

I'm not interested in working that way

I won't do spells for those who have no money

Because Pai Miguel isn't here for that

Ohhhhh

The other day in consultation with someone

Who wanted to know how their welfare would be

Pai Miguel turned to him and said:

You will get better

But you have to make an offering to the saints to clean yourself

Bless yourself with an onion at the first crossroads

And kiss the first creole woman you meet

But take care of that which is mine

Because my black woman has not died yet

And Pai Miguel's woman isn't there for kissing anybody

${ }^{22}$ A cumbuca is a pot made out of a gourd. 
And if someone has bad intentions

You can talk about it and he'll respond

Hey, this isn't a business, no

It isn't a business

And when Pai Miguel speaks because he is right

Otherwise Pai Miguel gets angry

He gets cross and rude

Hey, it's not a business, no

But if you have money to give to me

This is a business, yes

In Balabobá, a samba from 1930, the percussion-probably a bass drum - seems to be similar to that which was recorded in religious songs. The song talks about the elements to be found in a crossroads offering - a despacho: “There was also a stuffed chicken/ a rooster's head, a buzzard's feather Cabeça de galo, pena de urubu". The song also talks about a pai de santo and Xangô.

Oh balacuchê, bembere, babarabá

Oh cateretê, samba de balacubá

Oh balacuchê, bembere, babarabá

Oh cateretê, samba de balacubá

I saw there at the crossroads

A despacho with corn porridge

I saw there at the crossroads

There was also a stuffed chicken

A rooster's head, a buzzard's feather

There was also a stuffed chicken

A rooster's head, a buzzard's feather

Oh balacuchê, bembere, babarabá

Oh cateretê, samba de balacubá

Oh balacuchê, bembere, babarabá

Oh cateretê, samba de balacubá

[inaudible] up there

Atop the knock-down

[inaudible] up there

Atop the knock-down

One day he spoke with Xangô

And said that Pai [Camburi] is a good fellow

One day he spoke with Xangô

And said that Pai [Camburi] is a good fellow

Almost $60 \%$ of Patricio's repertoire was composed of sambas. In addition to the genre itself being linked to blackness, the verses of his sambas referred to black characters and experiences. Sometimes, they reinforced stereotypes such as the sensuality of the "mulatta" and legitimized the miscegenationist discourse. At other times, however, they emphasized symbols of black cultures, such as Afro-religiosities, food and dancing. Patricio's sambas brought to 
a greater audience aspects of the experiences of Carioca blacks - including race relations - in the first fifty years following the abolition of slavery.

Patricio Teixeira constructed his professional life by not being linked to a single musical style, adapting to the desires of the record-consuming public and radio audiences. As a singer, he needed to maintain his career. From the mid-1940s on, this began to decline, due to reasons such as changes in the music scene. Patricio was no longer called upon to sing for records. He remained at Radio Mayrink Veiga, however, with minor public appearances until he was removed in the mid-1950s.

\section{FINAL CONSIDERATIONS}

Some black musicians such as Patricio Teixeira experienced the transformations and novelties of the world of early $20^{\text {th }}$ century cultural entertainment as opportunities for professional insertion into a racist and unequal society. This professionalization was crucial in order to demarcate the place of black cultural identities in the Brazilian cultural and artistic fields, publicizing AfroBrazilians' artistic skills while singing about their daily lives, identities, and ties of belonging. The experience of singer Patrício Teixeira in the recording industry and radio is emblematic as it gave visibility to black cultural identities.

The music market prospered with the sounds of popular genres and styles, some of them referring to Afro-Brazilian religions. In many ways, these religions' orixá, rituals, and practices occupied cultural spaces in the city of Rio de Janeiro, either through the playful dimension of the samba party or through popular musicalities. Sacred elements overflowed into the festive, musical and playful city through various appropriations. These perceptions indicate forms of resistance for black cultural identities, demarcating the place of the sacred in the urban space.

Even as such songs and religiosities acquired folkloric and exotic connotations, songs with religious themes could take on cultural and political meanings, denoting possible ways of struggling for black identities and cultures, demarcating the presence and continuity of Afro-religious symbols in the city's artistic and festive scenes despite depreciations, persecutions and social regulations.

We must contextualize black experiences in the Atlantic by abolishing essentialisms from our analyses, as Paul Gilroy calls for us to do (2001, p. 18). According to this author, cultural exchanges were fundamental to the process of resistance to slavery and to the racisms produced after abolition. 
Considering the diversity of black experiences, we see the presence of Afro-religious symbols in Carioca public spaces as both constructions and resignifications, distancing ourselves from the idea of "African survivals". It is more relevant, we feel, to consider the perception of the reinventions, recreations, and recompositions conducted by black Cariocas in the city's larger social context (Capone, 2004, pp. 327-328).

Black identities are fundamental in the face of cultural and political domination fraught with conflicts and tensions. Nevertheless, Africanities must be understood as references for dealing with identity elements. They are the result of political and cultural constructions. Individuals and social groups carry with them elements of cultures, traditions, languages, and stories of their origins, but their cultural composition results from the encounter of cultural elements that connect in different spaces and times (Hall, 2006, pp. 325-327).

In the fight against intolerance and in search of legitimacy and social recognition, the presence of Afro-Brazilian religious elements in public spaces plays a predominant role as a form of daily resistance, not giving up their ritual practices and expanding their universe of influence. To some extent, the presence of religious symbols in musical recordings, on the beaches of Rio de Janeiro and elsewhere, may have collaborated to bring myths, entities, orixás, practices, and ritualistic values closer to the hearts of the Carioca population, helping to expand the scope of Afro-religiosities.

Our central concern here has thus been to perceive elements of the Afro-Brazilian religious universe as they spread through popular music, giving emphasis to cultural construction. This analysis' perspective is based on reframing: importing the meaning these songs and symbols had for the people of the time. Interchanges and hybridizations are the paths we have chosen to think about these issues, as we believe that cultures do not remain preserved in time.

Although black identities are important elements of survival in the face of cultural and political domination, care must be taken with the concept of "authenticity" so as not to lose sight of the varied sources and cultural exchanges that make up these identities. The meaning of cultural forms is not inscribed only on a person's inside, but constitutes a game of cultural relations (Hall, 2006, pp. 241-246). In this way, dialogues, correspondences, incorporations, and negotiations are at the center of the arguments presented in this article, which indicate possible ways of demarcating the presence of the Afro-Brazilian sacred in popular music on records and the radio waves. 


\section{REFERENCES}

A Noite. (1946, December 12). Patricio Teixeira. A Noite, p. 10.

Abreu, M., \& Dantas, C. (2007). Música popular, folclore e nação no Brasil, 1890-1920. In J. M. de Carvalho (Ed.), Nação e Cidadania no Império (pp. 123-151). Civilização Brasileira.

Amaral, R., \& Silva, V. G. da. (2006). Foi conta para todo canto: as religiões afro-brasileiras nas letras do repertório musical popular brasileiro. Afro-Ásia, (34), 189-235. https://doi.org/10.9771/aa.v0i34.21117

Araujo, A. L. A. de. (2015). J. B. de Carvalho e as gravações de macumba no Rio de Janeiro. Universidade Federal Fluminense.

Bahia, J., \& Vieira, C. (2017). Performances artísticas e circularidades das simbologias afrorreligiosas. Revista Brasileira de História das Religiões, (27), 171-188. https://doi.org/10.4025/rbhranpuh.v9i27.32449

Barreto, P. (João do Rio). (1951). As religiões do Rio. Edição da Organização Simões.

Bessa, V. de A. (2006). Um bocadinho de cada coisa: trajetória e obra de Pixinguinha. História e música popular no Brasil dos anos 20 e 30. Universidade de São Paulo.

Cacciatore, O. (1977). Dicionário dos Cultos Afro-Brasileiros. Editora Forense Universitária.

Capone, S. (2004). A busca da África no candomblé: tradição e poder no Brasil. Contracapa/Pallas.

Conduru, R. (2010). Das casas às roças: comunidades de candomblé no Rio de Janeiro desde o fim do século XIX. Topoi, (21), 181-182. https://doi.org/10.1590/2237$101 \mathrm{X} 011021010$

Cunha, M. C. P. (2001). Ecos da Folia. Uma História Social do carnaval carioca entre 1880 e 1920. Companhia das Letras.

da Baiana, J. (1966, August 24). Interview given to H. Bello de Carvalho ad A. de Alencar Pinto. Rio de Janeiro. Museum of Image and Sound, Rio de Janeiro, "Depoimentos para Posteridade" collection (transcribed in February 2010).

da Costa, J. L. (1930). Minha combuca [Song]. Odeon, nº 10663.

Dantas, B. G. (1988). Vovó Nagô e Papai Branco: usos e abusos da África no Brasil. Graal.

Dantas, C. M. V. (2019). Protagonismo Negro e Racismo na trajetória do músico e professor de violão Patricio Teixeira. Universidade do Estado do Rio de Janeiro/FFP.

Donga \& da Baiana, J. (1927). Dona Clara/Não quero mais [Song]. Odeon, nº 10084.

dos Prazeres, H. (1966, September 1). Interview given to J. Portela, A. Vasconcelos and I. Carvalho. Rio de Janeiro. Museum of Image and Sound, Rio de Janeiro, "Depoimentos para Posteridade" collection (transcribed in January 2010).

Ferlim, U. D. C. (2006). A polifonia das modinhas: diversidade e tensões musicais no Rio de Janeiro na passagem do século XIX ao XX. Unicamp.

Gilroy, P. (2001). O Atlântico Negro: modernidade e dupla consciência. Ed. 34; UCAM. 
Giumbelli, E. (2003). O 'baixo espiritismo' e a história dos cultos mediúnicos. Horizontes Antropológicos, (19), 247-281. https://doi.org/10.1590/S0104-71832003000100011

Hall, S. (2006). Da Diáspora. Identidades e mediações culturais. UFMG.

Hertzman, M. (2013). Making samba. A new history of race and music in Brazil. Duke University Press. https://doi.org/10.1215/9780822391906

Lopes, N. (1992). O negro no Rio de Janeiro e sua tradição musical: partido-alto, calango, chula e outras cantorias. Pallas.

Lopes, N., \& Simas, L. A. (2015). Dicionário da História Social do Samba. Civilização Brasileira.

Maggie, Y. (1992). Medo do feitiço: relações entre magia e poder no Brasil. Arquivo Nacional.

Moreira, B.; de Sousa, C. (1943). Pai Miguel [Song]. Victor, nº 80-0094-A.

Napolitano, M. (2010). Sambistas ou Arianos? A Crítica Racista e a Higienização Poética do Samba nos Anos 1930 e 1940. In M. L. T. Carneiro \& F. Croci (Eds.), Tempos de fascismos: ideologia, intolerância, imaginário (pp. 421-432). EDUSP.

Pandolfi, D. (2007). Os anos 1930: as incertezas do regime. In J. Ferreira \& L. de A. N. Delgado (Eds.), O Brasil Republicano (vol. 2). O tempo do nacional-estatismo: do início da década de 1930 ao apogeu do Estado Novo (2nd ed., pp.13-37). Civilização Brasileira.

Paranhos, A. (2015). Os Desafinados: Sambas e Bambas no "Estado Novo". Intermeios; CNPq; Fapemig.

Pixinguinha; de Almeida, C. (1932). Samba de fato [Song]. Victor, nº 33585.

Pixinguinha; Viana, G. (1938). Mulata baiana [Song]. Victor, $n^{\circ} 34346$.

Pixinguinha; Viana, G. (1938). Yaou africano [Song]. Victor, nº 34346.

Pixinguinha; Viana, G. (1941). Festa de Nanã [Song]. Victor, nº 34753.

Prandi, R. (2005). Segredos guardados: orixás na alma brasileira. Companhia das Letras.

Sandroni, C. (2001). Feitiço Decente: transformações do samba no Rio de Janeiro (1917-1933). Jorge Zahar.

Soares, F. E. (2016). "Fui o criador de macumbas em discos": Macumba, Samba e Carnaval pela trajetória de Getúlio Marinho da Silva. Rio de Janeiro, 1895-1964. Universidade Federal Fluminense.

Teixeira, P. (1930). Balacobá [Song]. Odeon, $n^{\circ} 10570$.

Teixeira, P. (1966, December 1). Interview given to L. Rangel, I. de Carvalho, A. Vasconcelos and R. Cravo Albin. Rio de Janeiro. Museum of Image and Sound, Rio de Janeiro, "Depoimentos para Posteridade" collection (transcribed in October 2016).

Wisnik, J. M. (1983). Getúlio da Paixão Cearense: Villa-Lobos e o Estado Novo. In E. Squeff \& J. M. Wisnik (Eds.), O Nacional e o Popular na Cultura Brasileira. Música (2nd ed., pp.129-191). Brasiliense.

Vianna, H. (2004). O Mistério do Samba. Jorge Zahar. 
Vieira, C. M. (2010). "Ninguém escapa do feitiço": música popular carioca, afrorreligiosidades e o mundo da fonografia (1902-1927)". Universidade do Estado do Rio de Janeiro; FFP.

Vieira, C. M., \& Nogueira, F.de J. (2018). The Generals of the Band: Music and the Black Diaspora in the Carioca Artistic Scene. Studia Religiologica, (51), 233-246. https://doi.org/10.4467/20844077SR.18.017.10101 